\title{
HANS JONAS ON THE ETHICS OF TECHNOLOGY
}

\section{Raja Oloan Tumanggor}

\author{
Faculty of Psychology, Universitas Tarumanagara, Jakarta
}

Email: rajat@fpsi.untar.ac.id

\begin{abstract}
This paper highlights Hans Jonas' technological ethic. For Jonas, traditional ethics is no longer adequate because the dynamics of modern technology are increasingly sophisticated. Initially, technology only helped humans learn natural laws so that nature could be used by humans according to their needs. However, the more advanced the technology, the side effects are also out of control and cannot be controlled. Therefore, Jonas offers ethical responsibility in the context of technology. This study examines Jonas's view of how humans should behave in today's technological developments. The method used is a qualitative method by analyzing Jonas' primary writings on technology ethics, then trying to describe them descriptively and critically. First of all, a brief biography of Jonas will be presented. Then discussed step by step his thoughts on technological ethics that come from primary and secondary sources. The result is that according to Jonas, humans have to change their way of life (lifestyle) in producing, consuming and caring about the environment. By creating a sense of human responsibility can prevent future calamities. This awareness is called Jonas with the principle of future responsibility.
\end{abstract}

Keywords: ethics, technology, Hans Jonas

\begin{abstract}
ABSTRAK
Studi ini menyoroti etika teknologi oleh Hans Jonas. Bagi Jonas, etika tradisional tidak lagi memadai karena dinamika teknologi modern semakin canggih. Pada awalnya teknologi hanya membantu manusia mempelajari hukum-hukum alam sehingga alam dapat dimanfaatkan oleh manusia sesuai dengan kebutuhannya. Namun, semakin canggih teknologi tersebut, efek sampingnya menjadi tidak terkendali. Oleh karena itu, Jonas menawarkan sebuah tanggung jawab etis dalam konteks teknologi. Studi ini mengkaji pandangan Jonas tentang bagaimana seharusnya manusia berperilaku dalam perkembangan teknologi saat ini. Metode yang digunakan adalah metode kualitatif dengan menganalisis tulisan utama Jonas tentang etika teknologi, kemudian mencoba mendeskripsikannya secara mendalam dan kritis. Pertama-tama, terdapat biografi singkat Jonas. Kemudian pemikirannya tentang etika teknologi yang bersumber dari sumber primer dan sekunder dibahas selangkah demi selangkah. Hasilnya adalah, menurut Jonas, manusia harus mengubah cara hidup (gaya hidup) dalam memproduksi, mengonsumsi, dan peduli terhadap lingkungan. Dengan menciptakan rasa tanggung jawab manusia, musibah di masa depan dapat dicegah. Kesadaran ini disebut oleh Jonas sebagai prinsip tanggung jawab masa depan.
\end{abstract}

Kata Kunci: etika, teknologi, Hans Jonas

\section{INTRODUCTION}

Nowadays the world is being dominated by technology. Technology offers a variety of new findings that make human life better. Technology provides comfort, improves human performance. Technology also makes humans easier to communicate with each other. The results of this technology really encourage us. So no wonder, people are competing to develop technology so that the comfort of human life can be even better. Because it is lulled by all the positive effects offered by this technology, Naisbitt (2001) said, we do not heed the consequences of technology and ask why the future seems unpredictable?

That can happen, said Naisbitt (2001), because we do not really understand where is the actual position of technology in our lives and what is more fundamental what exactly is the technology? We are complacent by the scent of technology, but we forget that the scent of death is also carried away by technology. Indeed, modernism which gave birth to technology, industry and information systems, as Barker (2003) said, has changed the face of the world and until now the process continues. This change is fast and promises to improve human well-being, but everything is not 
free. That change also brings the dark side. We are still proud if we master technology, nature, the world. Only when nature shows off, do humans begin to feel themselves nothing.

Fortunately, humans are now increasingly aware that technological development can threaten the future of humans and the world. Technology develops according to its own dynamics which we can no longer master. The problem is how can technology continue to develop and meet human expectations, but on the other hand, humans can avoid the catastrophe it causes? So the answer can be found in technology ethics which analyzes the ethical foundations that need to be considered in responding to technological developments. With the help of technology ethics, humans can anticipate negative aspects caused by technology. Hans Jonas offers a solution worth considering.

\section{RESEARCH METHODS}

This study uses a qualitative method with reference to the primary and secondary literature on Hans Jonas technology ethics. First of all, Hans Jonas' writings on technology ethics were studied. Starting from this article, a distinctive attitude from Hans Jonas was drawn. In order to better understand Hans Jonas 'ethical thinking, a secondary article that discusses Jonas' thinking is also analyzed. The results of his thoughts are then analyzed descriptively critically, in order to obtain a comprehensive thinking about Hans Jonas' technological ethics.

\section{RESULTS AND DISCUSSION}

Hans Hans Jonas, a German-American Jewish-born philosopher, tries to find a way out of this technological problem through his book Das Prinzip Verantwortung. Versuch einer Ethik fuer die technologische Zivilisation which was published in 1979. According to Jonas (2014), humans need new ethics to anticipate future conditions, because traditional ethics are no longer sufficient. Before reviewing further his thoughts on technology ethics need to be described in his biography. Hans Jonas was born May 10, 1903 in Monchengladbach, Germany. He studied philosophy under the guidance of Martin Heidegger and earned a doctorate in Marburg. When Hitler with his Nazi Party came to power in 1933, Hans Jonas left Germany and went to England, then to Palestine. After the war he returned to Germany to look for his mother. But apparently his mother was sent to the Auschwitz concentration camp. In 1950 Jonas went to Canada and then moved to New York City in 1955 and taught at the New School of Social Research until his death on February 5, 1993 (Ihde, 1979; Wagner-Döbler, 2017; Theis, 2019).

Hans Jonas wrote many articles and books centered on the social and ethical problems posed by technology. According to Jonas, human survival depends on our efforts to protect the planet and its future.

We are increasingly aware that technological development can threaten humanity's future. Technology continues to grow so we can no longer master it. Why does this condition go beyond traditional ethics? According to traditional ethics, if our will is good, then it can be assumed that the effect of the action is also good. But ethically we must choose when developing technology with the aim of making the world more human and threatening to destroy it? According to Jonas, in such situations it is not enough if ethics emphasizes that we act well, honestly and fairly, but must develop an ethical responsibility. Responsibility ethics is not bound to certain principles other than positive attitudes, but focuses on the consequences of our actions.

Max Weber (1864-1920), a German sociologist, distinguished two kinds of ethics, namely responsibility ethics (Verantwortungsethik) and good intentions (Gesinnungsethik) (2014). 
According to good intent ethics, the moral value of an act is determined by the intent of the perpetrator. Actions are considered good, if they arise from good will. A well-known example for that is the ethics of Immanuel Kant. According to this ethical principle, the de facto effect of actions carried out with good intentions is irrelevant in moral judgment. Therefore good goals should not justify the use of morally flawed ways. For example, for good purposes we can never lie. Moral value is determined not by the results of the action, but by its purpose. However, because in the real world there are many important goals that can only be achieved by violating moral norms, then this good intention ethic in the concrete world is difficult to realize.

While according to ethical responsibility, we are responsible for the results of our actions. One must account for what he did before his own conscience. He must hold rational considerations to compare the consequences of each of his actions. Then he chose the most suitable alternative to realize his ideals and could be justified before himself and others. Not realizing an important value simply because it does not want to violate moral rules precisely cannot be accounted for Jonas (1979)

For Jonas (2014), this ethic of responsibility gets new understanding in the context of technology. At present humans are starting to realize that in using and developing technology to master nature, it can at the same time also destroy the natural basis of the source of human life. If we used to ask enough, is an action good and can the consequences be justified? So now, even though the actions are good and the consequences can be justified, the same actions can destroy the world's ecosystems in the future, and that cannot be justified. In summary, it is not enough if ethics only talks about good, good consequences around us, just now. But what is far more important is the impact of our actions in the future.

For this reason, Hans Jonas put forward several principles that need to be considered. First, humans develop technology by studying natural law. But the more he succeeded, then he was also unable to master technological developments that ultimately threatened nature. This is for Jonas the 'apocalyptic' condition that is the human condition towards universal disaster if we allow the dynamics of technology to continue. This situation, according to Hans Jonas, can only be overcome with new ethics, namely: departing from this apocalyptic consciousness builds a heuristic fear. That is, humans must use fantasy and imagine the long-term consequences of our current technological civilization dynamics (Jonas, 1982).

After we fantasize about what will happen in the future, we build feelings that match what we imagine. This is the key to the following steps. We can do something now for the future if we believe that we are heading for destruction (Magnis-Suseno, 2014; Hauskeller, 2015). With this feeling we change our lifestyle such as how to produce, live consumptively and care for the environment. Thus a sense of responsibility arises to prevent future disasters. This awareness is what Hans Jonas mentioned as the principle of future responsibility. Jonas formulated it by: "Act in such a way that the consequences of your actions can be reconciled with the preservation of true human life on earth." (Gordon \& Burckhart, 2014; Saenko, Voronkova, Volk, \& Voroshilova, 2019).

Until here the task of ethics has not been completed. According to Jonas, what is required of us is that bad predictions must be given priority over good predictions. The prediction that technology can have a bad impact on the future of humans must be prioritized over the hope that technology can make humans more human. If there is indeed a risk of human destruction in the future, then the risk must be ended. Although the risk of eradication is uncertain, the issue of human lifestyles 
that cause the crisis of the earth's ecosystem has been ethically sufficient as a consideration so we are willing to make changes. For Jonas, humans can still live without the highest profit, but not with the highest evils (Magnis-Suseno, 2014).

The basis of the attitude of responsibility is an appeal or call from an object that moves our hearts to be responsible. Responsibility is not our necessity, but when dealing with objects, we feel called to be responsible because objects are weak and in need (Ristyantoro, 2005; Magnis-Suseno, 2014). According to Jonas, the moral imperative not to threaten human existence brings ethical implications of human ideas (understanding of human beings themselves). Human ideas contain categorical imperatives. Man's survival is a necessity, so that humans remain. For Jonas, humans are very high values. Therefore, our responsibility for survival is greater than the others.

Why should the existence of nature and humanity take precedence over letting it disappear? To explain this, Jonas came in with teleology. That is, whatever exists, exists for a purpose, then it is better if what is, is there rather than nothing (Ristyantoro, 2005). So directing to a goal means being positive towards yourself. Our responsibility for our own future and the integrity of nature is based on two reasons. First, the value of reality itself: it is good that things still exist. It is good if the ability to pursue goals is supported. Second, awareness that we are threatening that basic value. This responsibility is not based on values or norms, but especially because of calls from threatened reality. That responsibility is also comprehensive and totally means covering the whole object, from existence to the highest importance of the object (Magnis-Suseno, 2014, Becchi \& Tibaldeo, 2016; Thompson, 2020). Responsibility is directed towards the future. On the one hand, people are only responsible as far as he is in power. But on the other hand responsibility is not based on the object of responsibility. There are no norms that determine how responsibilities should be carried out. How that responsibility is carried out depends entirely on the awareness of the person responsible.

\section{CONCLUSIONS AND SUGGESTIONS}

The call to be responsible for the future is an important contribution from Hans Jonas, because he made us realize how the problem of human and earth integrity in the face of technological development is a serious problem. Hans Jonas is credited with placing concerns about the possibility of ecological disaster as a result of technological developments and progress seen from the perspective of responsibility. Jonas dared to be different in assessing technological progress. In addition, Jonas dared to say that the deontological ethics of Immanuel Kant with his categorical imperative principle was considered inadequate, because according to Jonas, motivation alone was not enough in ethical behavior. But what needs to be considered is whether ethical behavior has a good impact now and in the future?

Hans Jonas's warning we need to note that uncontrolled use of technology can threaten the integrity of human life and destroy the future of our beloved earth. So we must dare to change our lifestyle in production, consumption and leaving other bad habits. The problem is what is the boundary between what can and cannot be done to preserve human life and the universe. Not too easy to determine, because everyone has different needs.

\section{ACKNOWLEDGEMENT}

Researcher would like to thank all parties who have supported and been involved during the implementation of this research so that this research can run and be completed smoothly. 


\section{REFERENCES}

Barker, C. (2003). Cultures studies, theory and practice ( $2^{\text {nd }}$ ed.). Sage Publication Ltd.

Becchi P., Tibaldeo R. F. (2016) The vulnerability of life in the philosophy of Hans Jonas. Ius Gentium: Comparative Perspectives on Law and Justice, 55, 81-120. https://doi.org/10.1007/978-3-319-32693-1_5

Gordon, J.S. \& Burckhart, H. (2014). Global ethics and moral responsibility. Hans Jonas and his critics. Routledge.

Hauskeller, M. (2015). The ontological ethics of Hans Jonas. Medicine and Society, New Perspectives in Continental Philosophy, 120, 39-55. https://doi.org/10.1007/978-94017-9870-9_3

Ihde, D. (1979) Technology and the human: Hans Jonas. Technics and Praxis, 24, 130-140.. https://doi.org/10.1007/978-94-009-9900-8_10

Magnis-Suseno, F. (2014). 12 tokoh etika abad ke-20 (12 ethics philosophers of 20th century). Kanisius.

Naisbitt, J. (2001). High Tech High Touch. Mizan.

Jonas, H. (1979). Toward a philosophy of technology. The Hastings Center Report, 9(1), 34-43. https://doi.org/10.2307/3561700

Jonas, H. (1982). Technology as a subject for ethics. Social Research, 49(4), 891-898. https://www.jstor.org/stable/40971222

Jonas, H. (2014). Technology and responsibility: Reflections on the new tasks of ethics. Ethics and Emerging Technologies, 37-47. DOI: 10.1057/9781137349088_3

Ristyantoro, R. (2005). Etika masa depan Hans Jonas (The future ethics of Hans Jonas). Respons, $10(2), 36-47$.

Saenko, N., Voronkova, O., Volk, M. \& Voroshilova, O. (2019). The social responsibility of a scientist: The philosophical aspect of contemporary discussions. Journal of Social Studies Education Research, 10(3), 332-345. https://www.learntechlib.org/p/216457/.

Theis, R. (2019). Hans Jonas: Etappen seines Denkwegs. Springer VS.

Thompson P.B. (2020) Biotechnology, controversy and the philosophy of technology. In: Food and Agricultural Biotechnology in Ethical Perspective. The International Library of Environmental, Agricultural and Food Ethics, vol 32. Springer, Cham. https://doi.org/10.1007/978-3-030-61214-6_14

Wagner-Döbler R. (2017) Hans Jonas. In: Kindler Kompakt: Philosophie 20. Jahrhundert. J.B. Metzler, Stuttgart. https://doi.org/10.1007/978-3-476-05539-2_41 